\title{
Zorko Simčič
}

Zorko Simčič, narrador, dramaturgo y ensayista esloveno, miembro de la Academia Eslovena de Artes y Ciencias, nació en 1921 en Maribor. Allí empezó sus estudios pedagógicos, pero los terminó en Ljubljana que en aquel entonces fue ocupada por las fuerzas italianas y no por los alemanes como ocurrió en Maribor. Al final de la Segunda Guerra Mundial tuvo que abandonar la ciudad, se refugió primero en Austria y después en Italia para más tarde emigrar a Argentina. Allí terminó los estudios de antropología filosófica. Fue cofundador de la asociación cultural Acción Cultural Eslovena que se creó entre la numerosa emigración eslovena en Argentina. Durante doce años se dedicó también a la edición de la revista Entresiglos, la publicación cultural más importante de los emigrantes eslovenos. En 1994 regresó a Eslovenia. Hoy día Simčič figura entre los más destacados autores eslovenos.

Su primera novela El despertar (Prebujenje) se publicó en 1943 y fue galardonada con el Premio Prešeren de literatura. Un año más tarde salió su colección de textos satíricos La tragedia del siglo. Durante su exilio en Argentina publicó numerosos libros de ensayos, relatos breves, teatro y poesía. Entre sus obras cabe destacar la novela El hombre a ambos lados de la pared (Človek na obeh straneh stene), el misterio La juventud de fin temprano (Zgodaj dopolnjena mladost), la tragedia Agosto, el mes más largo (Tako dolgi mesec avgust, obra escrita en castellano y traducida al esloveno), la correspondencia con el poeta Stanko Majcen Los encuentros con Majcen (Srečanja $z$ Majcnom) y la novela Los últimos décimos hermanos (Poslednji deseti bratje).

La novela El bombre a ambos lados de la pared se publicó en 1957 en Argentina y sólo en 1991, el año en que Eslovenia ganó la independencia, también en su país de nacimiento. El autor recibió por ella uno de los premios nacionales más prestigiosos y la obra se reeditó varias veces. La novela entrelaza distintos planos geográficos y temporales, en ella hay numerosos rasgos modernistas, sobre todo el flujo de conciencia y el monólogo interior. El tema de la novela, desarrollado sobre el fondo de la época más cruel del Siglo XX, la Segunda Guerra Mundial, es un dilema íntimo y existencial que sufre el protagonista. Pero es, sin duda, también un testimonio que habla de la condición extranjera y del destino incierto de tantísimas personas desplazadas en este mundo. 